УДК 811.161 .2

В. І. Кажан, Р. П. Калініна

\title{
ЗАПОЗИЧЕНІ СЛОВА В СУЧАСНОМУ СЛОВНИКУ ПОПКУЛЬТУРИ
}

Кажан В. І., Калініна Р. П. Запозичені слова в сучасному словнику попкультури.

У статті здійснено аналіз запозичень, що називають явища масової культури; виявлено спільні для близькоспоріднених мов парадигматично-синтагматичні закономірності; засвідчено розширення словникового складу загальнолітературної мови.

Ключові слова: запозичене слово, попкультура, словотвірна система, функціонування.

Кажан В. И., Калинина Р. П. Заимствованные слова в современном словаре попкультуры.

В статье анализируются заимствования, называющие явления массовой культуры; обнаружены общие для близкородственных языков парадигматическо-синтагматические закономерности; засвидетельствовано расширение словарного состава общелитературного языка.

Ключевые слова: заимствованное слово, попкультура, словообразовательная система, функционирование.

Kazhan V. I., Kalinina R. P. The borrowed words in the modern dictionary of pop culture.

The article deals with the borrowings, which name the phenomena of a masscult; common paradigmatic and syntagmatic laws for common languages are found out; the expansion of dictionary structure common literature language is certified.

Key words: the borrowed word, pop culture, word formation system, functioning.

Мова масової комунікації має бути соціально значущою, доступною, інформативною, «дієвою для різних соціальних категорій і груп» [7, 20].

Вивчення мовних особливостей україномовних («Україна молода», «Критика», «Коментар», «Культура і життя») та російськомовних («Аргументы и факты», «Комсомольская правда», «Арт-Мозаика») газет та тижневиків за останній період (2008 - початок 2009 рр.) засвідчує розширення словникового складу загальнолітературної мови завдяки активному залученню іншомовної лексики зі сфери масової, або популярної, культури (музики, кіно, мистецтва, літератури, шоу-бізнесу). Через широку популярність позначуваних нею реалій найбільш схильною до сприйняття такої лексики є молодіжна аудиторія.

Ілюстративний матеріал демонструє відновлення більш ранніх запозичень, більшість із яких уже пристосувалася до мови-реципієнта, наприклад: укр.: колаж, дубляж, субтитри, бестселер; рос.: импресарио, ротация, комиксbl, кинодистрибьюторы тощо. Запозичені терміни-слова наділені словотворчими потенціями, що виявляються у формуванні похідних одиниць, переважно прикметників, які використовуються у прямому значенні. Вони утворюються: а) суфіксальним способом: укр.: хітовий (сингл); топові (виконавці), поп-фолькова (мелодія); аматорський (фільм); кобзарство; бан- 
дурництво; рос.: фентезийные (сказания); медийные (лица); мейнстримное (звучание); фанковые (ритмы) онлайновая (школа); хэдлайнерский (ведущий) та ін.; б) префіксальним способом (надзвичайно рідко): укр.: антимейнстрім, суперхіти, рос.: неформат, спродюсировать.

До словотвірної системи обох мов залучаються інтернаціональні компоненти, які входять до морфемної будови складних слів. Подібне явище набуває подальшого поширення. Наприклад: укр.: радіодіджей, мінібенефіс, мега-зірка, кінопортал, телешоу; дискографія, кінофундація, кінокутюр'є; мегахіт; рос.: киношлягер, ретросаунд, электро-поп; минисериал (лента); монодрама, мегапопулярныци, макси-сингл, киносэмпл, мини-фест тощо.

У мові ЗМІ активізується також процес утворення нових складених складних слів (за термінологією В. М. Немченка - 4) способом осново- та словоскладання, що свідчить про розвиток рис аналітизму в українській i російській мовах. Можна виділити такі моделі складних слів:

- запозичене слово + запозичене слово (як правило, з англійської мови): укр.: фольк-рок, інтернет-портал, реп-кліп, реаліті-шоу, поп-арт, иоу-кастинг; рос.: триллер-римейк, рэп-баттл, имидж-дизайнер, реггихит, фээн-стори, альтер-эго, брейк-баттл, инди-лейбл, лонг-плей, лейтин-рок та ін.;

- запозичене слово + питоме слово: укр.: інтернет-голосування, соулзірка, гранд-роль, арт-ярмарок, фольк-запис, медіанасильство; рос.: шорт-лист, трек-лист, камео-роль, баттл-песня, демо-запись, письмоэмбарго, медиа-поддержка. У подібних моделях запозичене слово займає переважно препозицію, зрідка - постпозицію;

- запозичене слово + старе запозичене слово, яке давно ввійшло в лексичну систему мови: укр.: топ-позиція, радіо-хіт, фільм-фентезі, рекордлейбл, інтернет-форум, мейнстрім-рок, медіа-магнати, рок-бард; рос.: кавер-версия, бэк-вокал, актер-хоббит, демо-версия, фэшн-канал, саундпродюсер, фольк-авангард, рок-тоталитаризм, рэп-радиостанция, рокклише, рок-стереотипьл.

Менш активними є трикомпонентні найменування, наприклад, xinхоп-батл, хип-хоп-вечеринка (среда, тусовка, сообщество, кумир), проектвеб-портал, етно-диско-вечорниці; нон-стоп-экин; вело-экстримтриалисты, панк-рок-кафе, готик-фолк-сцена, ритм-энд-блюз.

Варто звернути увагу на термінологічну номінацію словосполучень у сфері масової культури, яка деякою мірою порушує мовний стандарт. 3 іншого боку, утворення словосполучень, які складаються з двох, трьох і більше компонентів, дозволяє систематизувати і розширити стрижневі поняття за родо-видовими ознаками, надати їм деякої виразності та експресивності. Напр.: укр.: панк-рокова композиція, художньо-аудіовізуальнотеатрально-літературно-філософський проект; рос.: скейт-хардкорпанковые группы, мюзиклово-джазовые мелодии та ін. 
За характером семантико-синтаксичних і морфологічних зв'язків між компонентами складені складні двокомпонентні найменування (терміниіменники) можна поділити на два типи.

Перший тип охоплює слова, утворені поєднанням в єдине ціле двох самостійних іменників, синтаксичні відношення між якими є рівноправними. Напр.: укр.: мейнстрім-рок, гот-патріот, треш-версія, беквокалістка, хіт-журнал; рос.: фешн-патриот, блюз-рок, топменеджмент, рок-артист, бэк-музыканты.

Другий тип - це найменування, з яких перший (рідше другий) компонент є скороченою основою. У цьому типі виділяються такі підтипи:

а) $з$ основою на -о: укр.: промо-акції (від промоут - сприяти, допомагати), промо-тур, етно-хаус (від етнос - народ); рос.: демо-кассета (від демонстраційний), промо-сингл та ін.;

б) з основою поп- (від популярний) і арт- (від артистичний, художній): укр.: поп-хористка, поп-чарт, арт-інституції, поп-сингл; рос.: артмозаика, арт-рок, поп-лицо, поп-деятель, поп-представление тощо;

в) з основою-абревіатурою (зафіксовано незначну кількість одиниць): укр.: піар-агентство, віп-трибуна; рос.: пиар-ход, вип-сектор, вип-билеть тощо;

г) $з$ основою (першою, другою, з обома) - іншим скороченням на зразок: укр.: фан-сектор, рок-фест; рос.: фран-зона, брит-поп тощо.

Зауважимо, що переважна більшість скорочених основ у цьому типі набула «статусу префіксоїдів, що сприймаються як усічення прикметникових основ» $[3,218]$.

Мова ЗМІ намагається (хоча не завжди послідовно) нейтралізувати в певний спосіб значну кількість запозичених слів:

- через підбір синонімів із питомої лексики (інколи спостерігається і в межах одного контексту) або запозичених слів, які давно ввійшли в стандартну мову, наприклад: укр.: лейбл - група (компанія, студія); трек - пісня (композиція); ремейк (римейк) - перезапис (фільму); генерація - покоління; рос.: диджей - ведучий; данс - танець; сингл - компакт-диск, продакин - виробництво та ін.;

- через пояснення описовим способом у тексті змісту запозиченого слова, наприклад: укр.: кіч (стає лінією з найпопулярніших форм масової культури); графіmi (у Нью-Йорку стрімко розвинулося нове урбаністичне мистецтво); емо (скорочено від emotion - емоційний) - молодіжна субкультура, яка бере свої початки з 80-х років на Заході; Вплив Заходу, розвиток новітніх технологій призвели до появи молодіжних субкультур: готи, емо, панки, репери, регzі, хули, скінхеди, рокери тощо. Їх часто одним словом називають нефори, або неформали; рос.: Сейзль (продавцы рекламного эфира) гораздо оперативнее реагируют на колебания рынка; камео - із підзаголовка: Англ. слово "сатео» буквально переводится как «камея», т.е. ювелирное украшение с чьим-либо портретом. В кино «камео» означает нечто иное - участие в фильме звезды, которая исполняет эпизодичес- 
кую роль. Термин впервые был использован продюсером М. Тоддом применительно к фильму «Вокруг света за 80 дней» (1956), в котором насчитывается 44 камео; И всем любителям боевиков в стиле "нон-стоп-экин" (то есть безостановочного действия, которое не отпускает зрителей до самого кониа фильма) рекомендую ленту к просмотру; Шесть мест съем$\kappa и$, или на языке клипмейкеров, шесть локэйшенов.

Перед нами зразки текстів-пояснень, які популяризують знання серед широкого кола читачів, тому вони мають бути не тільки інформативними, соціально значущими, але й доступними, що досягається акцентуванням уваги не тільки на родо-видових ознаках абстрактних понять, а й на коротких історичних екскурсах про час, місце виникнення та етимологію термінів. Слід відзначити також використання емоційної лексики на противагу, приміром, науковим текстам.

Якщо в газетних текстах відсутні вказані засоби нейтралізації іншомовної лексики, то більша частина читачів не спроможна сприйняти інформацію через відсутність у контексті тлумачення значення запозичених одиниць, якими деякі тексти перенасичені. Наведемо приклади: Жанр значення не має - від традиційних інструментів на зразок живопису до мультимедіа, інсталяцій, гепенінгів тощуо, головний критерій - індивідуальність художника; Она его муза, импресарио, менеджер, имиджмейкер и домоправительница в одном лище.

Певна кількість запозичених у сфері масової культури слів відповідає вимогам, що висуваються до термінів: бути максимально точними і короткими. Запозичення нерідко відбувається саме задля економії мовних засобів порівняно з питомими чи калькованими описовими виразами. Наприклад: укр.: гран-npi - найвища нагорода; реноме - репутація, усталена думка про кого-, що-небудь; фентезі - літературний стиль - ненаукова фантастика; фолькзапис - запис народної музики; таблоїд - газета невеликого формату (зазвичай бульварного змісту); рос.: блокбастер - кінофільм (вистава) з масштабним зніманням, масовими сценами; перформанс (перфоманс) - вид художньої творчості, який об'єднує театр з образотворчим мистецтвом; ремикс (римикс) - новий варіант, переробка старої мелодії пісні; чарты - списки популярності (рейтингу) виконавців; комикс - популярна серія малюнків з короткими оповідями, які утворюють суцільну розповідь розважального характеру.

Деякі запозичені слова, що донедавна вживалися у вузькій термінологічній сфері, починають долати цей бар'єр, переходять до загальнолітературної мови, розширюючи при цьому свої семантичні можливості і нерідко набуваючи нових значень. Наприклад: Продюсер зразу після перемоги запросив співия на свій лейбл, де той $і$ випустив свій дебютний альбом; Лейбл «Імперія» стрімко ввірвався до вітчизняного шоу-бізнесу (контексти допомагають 3'ясувати, що слово «лейбл» - це не тільки фірмовий знак, яскрава наліпка, що прикрашає готовий одяг, а й музична група, фірма, 
студія); Любители рок-музыки наверняка его запомнили по совместному треку с рок-группой; у словосполученнях: танцевальные треки, скачивание треков, трек «Полночь»; заглавный трек альбома (слово «трек (треки)» набуло значення «музикальна композиція (пісня)»); Создание торговых марок - вот мейнстрим современного искусства. Здесь все важно: извет, линия, образ, музыка, слово (за словником, мейнстрім - джазовий термін, яким позначають помірно прогресивні напрямки будь-якого джазового стилю; у статті слово вжито у значенні «головний напрямок у мистецтві взагалі»); ще один контекст з останнім словом: заголовок «Неформат» - в бой с мейнстримом!» («Неформат» - незалежна літературна премія). Термін набув узагальненого значення: «літературний твір, який нічим не виділяється із загальної течії, тобто звичайний формат, позбавлений оригінальності, живих прийомів, свіжих типів сприйняття тощо.

У мові газет спостерігаємо спільні для близькоспоріднених мов парадигматичні й синтагматичні закономірності: запозичені слова залучаються до процесу переосмислення значення, розширення лексичної сполучуваності, що нерідко призводить до метафоричних переносів і як наслідок - до формування експресивно-стилістичного змісту. Наприклад: укр.: фортепіанний альянс; яскравий колаж булгаковського бестселера; гуру маркетингу; гаряча ротація; рос.: саундтрек современной жизни; брендированный мир; драйвовая гитара та ін.

Експресивність мас-медійних текстів забезпечується й утворенням від опорних запозичених слів похідних одиниць, що мають яскраві ознаки оказіональності. Наприклад: укр.: кінографоманія; Бондіада (від Бонд); кінофест (фест - від фестиваль); атракціономанія; російський шоубіз (замість шоу-бізнес); рокенролльно (рос.: рок-н-ролльно; по-рок-нролльному); рос.: запитченнылй (від питч); забрейковать (від брейк); лоходэнс; хип-хопчик; баттлиться (від баттлы - танцювальні битви); поттериана (від Поттер); рокерша; франатить (від фанат); випь и випушки; песни-несаундтреки і т.ін.

Завдяки схожості звукової оболонки запозичені одиниці залучаються до мовної гри, що надає тексту додаткової експресії й оригінальності. Цікавою є така ілюстрація зі словами сбрендивиие і брендинг: Заголовок «Сбрендившие...» (іронічне просторічне слово утворено від дієслова «сбрендить» - утратити розум; «сбрендить» - від «бренд» - алкогольний напій). Контекст: «Украина, как и другие страны постсоветского пространства, переживает бум брендинга» (брендинг - від бренд - торгова марка).

Загадковість і зацікавленість викликають ті запозичені слова, які дотепер ще не зафіксовані тлумачними словниками та словниками іншомовних слів (це явище спостерігаємо в обох мовах). Наприклад: укр.: беквокал (вокальний супровід сольного номера); реліз (презентація альбому записаного диску); фронтмен (соліст, керівник групи); біт (музикальний ритм); рос.: кавер-версия (один виконавець подає свою версію композиції 
другого без його участі); регzи (музикальний стиль); шорт-лист (короткий список-перелік); хэдлайнер (ведучий заходу); райдер (список запитів виконавця до організаторів гастролей) тощо.

Отже, за умови збереження комунікативності та функціональностилістичних обмежень запозичення стають одним із джерел поповнення сучасного словника популярної культури. Розширюється сфера використання інтернаціональної лексики.

Прогнозуємо, що певний арсенал запозичених одиниць перейде до загальнонародної мови. Припускаємо, що число іншомовних слів у мові сучасних ЗМІ буде певною мірою відрегульовано (перш за все через пошук рівнозначного питомого матеріалу, семантично еквівалентного запозиченому). У такому процесі нормалізації й упорядкування доцільно враховувати культурно-мовну компетенцію читачів, прагнути до помірного запозичення.

\section{Література}

1. Большой словарь иностранных слов. - М.: ООО «Дом Славянской книги», 2009. - 992 c.

2. Великий тлумачний словник сучасної української літературної мови. - К.: Ірпінь. ВТФ «Перун», 2009. - 1736 с.

3. Колоїз Ж. В. Українська оказіональна деривація: [монографія] / Жанна Василівна Колоїз. - К.: Акцент, 2007. - 310 с.

4. Немченко В. Н. Современный русский язык. Словообразование / Василий Николаевич Немченко. - М.: Высшая школа, 1984. - 255 с.

5. Новый словарь иностранных слов / [глав. ред. В. А. Адамчик]. - М.: АСТ; Мн.: Харвест, 2007. - 1152 с.

6. Современный толковый словарь русского языка / [глав. ред. С. А. Кузнецов]. СПб: Норинт, 2004. -960 c.

7. Солганик Г. Я. Общие особенности языка газеты / Г. Я. Солганик // Язык и стиль средств массовой информации и пропаганды. - М.: МГУ, 1980. - С. 5-23. 